\title{
Levealder og dødsårsaker hos menn undersøkt ved helsekontroll i 1964
}

Engelsk oversettelse av hele artikkelen på www.tidsskriftet.no

Podkast til artikkel www.tidsskriftet.no/podkast

\begin{abstract}
Sammendrag
Bakgrunn. Formålet med studien var å beregne assosiasjonene mellom blodtrykk, kroppsmasseindeks og røykevaner, registrert i rutinemessige helsekontroller hos bedriftslegen, og levealder og årsaksspesifikk dødelighet gjennom flere tiår.
\end{abstract}

Materiale og metode. Deltakere fra det såkalte Linoljeforsøket ble fulgt fra 1967 og ut 2005 med henblikk på totaldødelighet og årsaksspesifikk dødelighet i Dødsårsaksregisteret. Studiepopulasjonen utgjorde 15934 menn som var født 1905-14 og som var i arbeid i 1967. Analysene omfattet ulike multivariate regresjonsmetoder.

Resultater. I alt 15535 deltakere (97,5\%) var døde, og gjennomsnittlig dødsalder var 76,6 år (SD 9,1). Blodtrykk, kroppsmasseindeks og sigarettrøyking var assosiert med alder ved $\mathrm{d} ø \mathrm{~d}$ og dødelighet for hjerte- og karsykdom, lungekreft og sykdom i respirasjonssystemet. Høyt systolisk blodtrykk ( $\geq 160 \mathrm{~mm} \mathrm{Hg}$ ) var assosiert med redusert levetid på fem år, 15 sigaretter daglig med en reduksjon på 3,5 år, fedme med 1,4 år og sikker forhøyet senkningsreaksjon med 3,3 år kortere levetid. Overdødeligheten vedvarte gjennom hele oppfølgingsperioden for alle faktorene, men avtok etter hvert for høyt blodtrykk og høy senkning. Assosiasjonene for røyking og fedme endret seg ikke over tid. Assosiasjonene for røyking var svakere enn i de fleste tidlige studier.

Fortolkning. Resultatene av rutinemessige helsekontroller i bedriftshelsetjenesten kan predikere tapte leveår gjennom flere tiår.

\section{Tor Bjerkedal}

tor.bjerkedal@getmail.no

Institutt for helse og samfunn

Universitetet i Oslo

og

Militærmedisinsk epidemiologi

Forsvarets sanitet

\section{Petter Kristensen}

Statens arbeidsmiljøinstitutt og

Institutt for helse og samfunn

Universitetet i Oslo

\section{Randi Selmer}

Nasjonalt folkehelseinstitutt

Tidlig i 1960-årene ble det satt frem en hypotese om at kosttilskudd av linolje, med høyt innhold av den umettede fettsyren linolensyre, kunne forebygge iskemisk hjertesykdom (IHD) (1). For å teste denne hypotesen startet en arbeidsgruppe med assistanse av norske bedriftsleger et ettårig kontrollert klinisk forsøk i 1964. Det ble benevnt «Linoljeforsøket» og omfattet over 16000 menn født i perioden 1905-14 $(2,3)$. Data om etablerte og mistenkte risikofaktorer for iskemisk hjertesykdom ble innhentet fra bedriftslegenes journaler og var alt vesentlig basert på tidligere rutinemessige helsekontroller (3). Dette var en periode hvor enkelte bedriftsleger satte søkelyset på folkehelseproblemer, ikke minst hjerte- og karsykdom $(4,5)$.

Linoljeforsøket ble fullført, selv om det raskt ble klart at tilskudd av linolje ikke hadde den forventede effekten (6) - behandlingen ga ingen helsemessig gevinst sammenliknet med placebo $(2,3)$. Derimot var etablerte risikofaktorer som høyt blodtrykk (7), høy kroppsmasseindeks (BMI) (8) og sigarettrøyking (9) assosiert med økt risiko for iskemisk hjertesykdom $(2,3)$. Deltakerne i Linoljeforsøket ble videre fulgt opp fra 1966 til 1982, og de samme risikofaktorene var da assosiert med økt totaldødelighet (10). På grunn av mistanke om at også senkningsreaksjonen var forbundet med risikoen for iskemisk hjertesykdom (4), ble også denne registrert og funnet å være assosiert med så vel slik sykdom (3) som totaldødeligheten (10).

Deltakerne i Linoljeforsøket ble fulgt videre som en observasjonsstudie med kobling til Dødsårsaksregisteret ut 2005. På dette tidspunktet var nesten alle døde - de overlevende var 91-100 år gamle.

Nytten av rutinemessige helsekontroller av presumptivt friske voksne er omdiskutert
(11). Formålet med denne studien var å beregne om og i hvilken grad resultatene av slike rutinekontroller hos bedriftslegen kan predikere tap av leveår og dødelighet av ulike årsaker. I tillegg til blodtrykk, kroppsmasseindeks og røykevaner fulgte vi opp sammenhengen med senkningsreaksjonen $(3,10)$.

Samme år som Linoljeforsøket ble gjennomført, ble det også gjort en stor blodtrykksundersøkelse i Bergen. Denne er senere blitt fulgt opp med henblikk på dødelighet av ulike årsaker, med spesiell vekt på hjerte- og karsykdom (12). Få år senere ble Oslo-undersøkelsen gjennomført blant 40-årige menn. Den er senere fulgt opp (13).

Basert på data fra nasjonale og internasjonale befolkningsundersøkelser er ulike risikomodeller for hjerte- og karsykdom utviklet. Blodtrykk og sigarettrøyking er med i alle disse. SCORE-modellen (14) inngår i de europeiske retningslinjene for forebygging av hjerte- og karsykdom, mens den tilsvarende NORRISK-modellen er del av de norske (15). Vi vil relatere våre funn til de nevnte norske undersøkelsene og risikomodellen NORRISK.

\section{Materiale og metode}

\section{Deltakere}

Deltakerne i Linoljeforsøket var presumptivt friske menn i 50-årene som i 1964-65 ble rekruttert av bedriftslegene ved 280 bedrifter. Over $40 \%$ bodde på Østlandet og var ansatt i sekundærnæringsbedrifter som manuelle arbeidere. I alt ble 16608 menn rekruttert, herav 16364 født 1905-14 (3). Det er ikke klart hvor mange inviterte som avsto fra deltakelse, men 208 menn fra fire bedrifter ble ikke inkludert på grunn av bedriftslegens sykdom eller død (3). I denne oppfølgingen deltar de 15934 som var født $i$ 1905-14 og som var i arbeid (hadde pensjonsgivende inntekt) i 1967.

\section{Datakilder}

Bedriftslegene fylte ut et registreringsskjema for hver deltaker tidlig i 1965. Skje-

\section{Hovedbudskap}

- Resultatene av rutinemessige helsekontroller i bedriftshelsetjenesten kan predikere tap av leveår over flere tiår

- Assosiasjonene ble svekket over tid for høyt blodtrykk, men ikke for røyking 
maet inneholdt blant annet opplysninger om aktuelle røykevaner og resultater fra helseundersøkelser i bedriften de foregående to år. Etter innhenting av fødselsnummer ble informasjon fra folke- og boligtellingen 1960 og Dødsårsaksregisteret koblet til materialet. Regional komité for medisinsk forskningsetikk tilrådet at prosjektet ble gjennomført.

\section{Forklaringsvariabler}

Opplysninger om sivilstatus, bostedsregion, næringsgruppe og yrkesgruppe ble innhentet fra folke- og boligtellingen 1960. Systolisk og diastolisk blodtrykk, høyde og vekt som var registrert i bedriftshelsetjenesten i løpet av de siste to år ble inkludert. Systolisk blodtrykk ble gruppert i ni kategorier, mens diastolisk blodtrykk ikke ble brukt i hovedanalysene (16).

På grunnlag av høyde og vekt ble kroppsmasseindeks (BMI, $\mathrm{kg} / \mathrm{m}^{2}$ ) utregnet og gruppert som undervekt $\left(<18,5 \mathrm{~kg} / \mathrm{m}^{2}\right)$, normalvekt $\left(18,5-24,99 \mathrm{~kg} / \mathrm{m}^{2}\right)$, overvekt $\left(25,0-29,99 \mathrm{~kg} / \mathrm{m}^{2}\right)$ eller fedme $(\geq 30 \mathrm{~kg} /$ $\mathrm{m}^{2}$ ). Fra registreringsskjemaet ble også antall sigaretter per dag inkludert og gruppert i fire kategorier.

Skjemaet inneholdt en registrering om deltakeren hadde forhøyet $(>15 \mathrm{~mm}$ ) senkningsreaksjon ved gjentatte målinger over flere år. Den ble klassifisert av bedriftslegen som «sikkert forhøyet», «tvilsomt forhøyet» eller «ikke forhøyet» (3). Forklaringsvariablene og deres fordeling er angitt i e-tabell 1.

\section{Utfallsvariabler}

Dødsdato og underliggende dødsårsak ble innhentet fra Dødsårsaksregisteret. Foruten død av alle årsaker ble årsaksspesifikk død registrert for sirkulasjonssystem, herunder iskemisk hjertesykdom og hjernekarsykdom (slag), kreft, herunder kreft i bronkier og lunge (lungekreft), respirasjonssystem og død av ytre årsaker. Dødsårsakene ble i ulike tidsavsnitt klassifisert i henhold til ICD-7, ICD-8, ICD-9 og ICD-10. Koder og tidsavsnitt for klassifiseringen er gjengitt i e-tabell 2.

\section{Statistiske analyser}

Statistikkpakken Stata versjon SE11.1 ble benyttet. Vi presenterer flere ulike mål på sammenhengen mellom risikofaktorene og totaldødelighet og årsaksspesifikk dødelighet. Vi beregnet gjennomsnittlig alder ved død gruppert etter forklaringsvariablenes kategorier og anvendte multippel lineær regresjon, Coxregresjon og Kaplan-Meier-kurver.

Multippel lineær regresjonsanalyse ble utført for alle deltakere som døde i oppfølgingsperioden 1967-2005. Estimerte koeffisienter representerer sammenhengen mellom livslengde, forklaringsvariablene hvor mange år lenger eller kortere individer med ulike risikofaktorer levde i gjennomsnitt sammenliknet med personer i en gitt referansegruppe. Lineær regresjon er mulig fordi omtrent alle er døde. Alder ved død representerer den kumulative effekten av dødelighetsratene fra 50-årsalderen.

Cox-regresjon er sentralt innen overlevelsesanalyse - den modellerer de aldersspesifikke dødelighetsratene. Resultatet er estimerte hasardratioer (HR), som er forholdet mellom dødelighetsratene i ulike kategorier av en forklaringsvariabel. Det antas at hasardratioen er den samme for alle aldre/ tidsintervaller. For å vurdere om risikofaktorenes relative effekt avtok over tid/alder beregnet vi hasardratioen for død av alle årsaker i fire observasjonsperioder (1967-76, 1977-86, 1987-96 og 1997-2005).

Vi har lagt inn alle forklaringsvariabler som kategorier. I tillegg har vi gjort analyser med systolisk blodtrykk som en kontinuerlig risikofaktor og beregnet hasardratioen per $15 \mathrm{~mm} \mathrm{Hg}$ økning for hele perioden og de første 20 årene av oppfølgingen. Ved modellering av dødelighetsrater for spesifikke årsaker ble deltakere sensurert ut ved tidspunktet for eventuell død av andre årsaker, utvandring eller ved observasjonstidens slutt 1.1. 2006.

Vi fulgte alle årskullene fra alder 62 år. Beregning av overlevelse fra fylte 62 år (1967-76) ut 2005 ble gjort i Kaplan-Meierkurver for utvalgte kombinasjoner av systolisk blodtrykksnivå og røykevaner. Kurvene viser andelen som fortsatt er i live ved ulike aldre etter start av oppfølgingen. Kurvene ga grunnlag for beregning av median overlevelse, det vil si den alderen da halvparten av gruppen er døde.

I alle regresjonsanalysene ble $95 \%$ konfidensintervall (KI) beregnet for punktestimatene (koeffisient for endring i livslengde og hasardratio).

\section{Resultater}

Død av alle årsaker

I oppfølgingsperioden 1967-2005 døde 15535 (97,5\%). 27 deltakere utvandret i perioden og 372 var fortsatt i live 1.1. 2006. Andel overlevende gruppert etter forklaringsvariablene er vist i e-tabell 1 . Prosent overlevende var som forventet positivt assosiert med sivilstatus gift, bosted i Vest-Norge, ikke-manuelt yrke, lavt systolisk blodtrykk, normalvekt, ikke røyking og ikke forhøyet senkningsreaksjon. Det samme mønsteret gjenspeilet seg i den multivariate analysen av livslengde (tab 3 ). For de fleste kategorier var assosiasjonene moderate (+/ 2 leveår), men estimatene for redusert livslengde var vesentlig høyere for høyt systolisk blodtrykk - fem år i gjennomsnitt der dette var $\geq 160 \mathrm{~mm} \mathrm{Hg}$. Estimatene var også noe høyere for de høyeste røykekategoriene $(3,5$ år for $\geq 15$ sigaretter daglig) og for forhøyet senkningsreaksjon (3,3 år). Fedme var assosiert med 1,4 år og undervekt med 1,7 år kortere livslengde enn hos de normalvektige.

Figur 1 viser overlevelsesfunksjonen fra 62 års alder for utvalgte risikokategorier. Ut fra kurvene vil estimert median overlevelse for ikke-røykere med systolisk blodtrykk
$<140$ mm Hg være 81,2 år. For røykere ble overlevelsen estimert til 75,2 år ved blodtrykk på 140-159 mm Hg. Ved blodtrykk $\geq 180 \mathrm{~mm} \mathrm{Hg}$ (uavhengig av røykevaner) var estimert overlevelse 72,5 år. Av figur 1 kan man lese at beregnet andel deltakere i live ved alder 80 år var $19 \%$ for dem med blodtrykk $\geq 180 \mathrm{~mm}$ og $60 \%$ for ikke-røykere med blodtrykk $<140 \mathrm{~mm} \mathrm{Hg}$.

Figur 2 viser at hasardratioestimatene for risikofaktorene i assosiasjon med død av alle årsaker var økt i alle tidsavsnitt mellom 1967 og 2005. Effekten av høyt systolisk blodtrykk og forhøyet senkning viste imidlertid en synkende tendens, mens estimatene for røyking og fedme var stabile over tid.

\section{Årsaksspesifikk død}

Antall døde fordelt på de ulike dødsårsaker er gjengitt i e-tabell 2. Halvparten døde av sirkulasjonssykdommer og en firedel av kreft.

Assosiasjonene mellom risikofaktorene og sykdom i sirkulasjonssystem inkludert iskemisk hjertesykdom og slag er presentert $\mathrm{i}$ e-tabell 4. Økende systolisk blodtrykk var sterkt assosiert med økende hasardratioestimater, sterkere for slag enn for hjertesykdom. Dødelighetsratene var henholdsvis 5,3 og 2,8 ganger høyere i den høyeste blodtrykkskategorien enn i referansekategorien. Fedme og røyking var bare moderat assosiert med dødelighet av sirkulasjonssykdommer, inklusive iskemisk hjertesykdom og slag. Sikkert forhøyet senkning var assosiert med iskemisk hjertesykdom, med et hasardratioestimat på 1,7 .

Dødsårsakene kreft og lungekreft var bare moderat assosiert med risikofaktorene, med unntak av røyking (e-tab 5). Hasardratioestimatet for lungekreft hos røykere som konsumerte minst 15 sigaretter daglig var 5,5. Lungekreft var også assosiert med sikkert forhøyet senkning. Død av respirasjonssykdom var assosiert med lavere kroppsmasseindeks, røyking og forhøyet senkning. For død av ytre årsaker ble det funnet et liknende mønster, men med noe svakere hasardratioestimater for kroppsmasseindeks og røyking.

Hasardratioestimatene i e-tabell 4 og e-tabell 5 ble bare i liten grad endret av den multivariate modellen med inkludering av alle risikofaktorene (data ikke vist). Det eneste unntaket var hasardratio for sirkulasjonssykdommer i assosiasjon med fedme, hvor estimatet var 1,7 før justering og 1,4 etter justering for systolisk blodtrykk.

I overlevelsesanalysen, der systolisk blodtrykk ble inkludert som en kontinuerlig variabel, utgjorde en økning i systolisk blodtrykk på $15 \mathrm{~mm} \mathrm{Hg}$ en hasardratio på 1,27 $(1,25-1,29)$ for sirkulasjonssykdommer i oppfølgingsperioden under ett. Blodtrykkseffekten var noe sterkere de første 20 årene av oppfølgingen, da en økning på $15 \mathrm{~mm} \mathrm{Hg}$ var assosiert med en hasardratio på 1,32 $(1,30-1,35)$ for sirkulasjonssykdommer, $1,25(1,22-1,28)$ for iskemisk hjertesykdom og 1,48 $(1,41-1,55)$ for død av slag. 
Tabell 3 Endringer i livslengde i assosiasjon med sosiodemografiske kjennemerker 1960 og enkelte resultater av bedriftslegers helsekontroll hos 15535 deltakere i Linoljeforsøket som døde mellom 1967 og 2005. Lineær regresjonsanalyse

\begin{tabular}{|c|c|c|c|c|}
\hline Kategori & Dødsalder (år) (gjennomsnitt) & SD & Forskjell1 & $95 \% \mathrm{KI}$ \\
\hline Total & 76,6 & 9,1 & & \\
\hline \multicolumn{5}{|l|}{ Sivilstatus 1960} \\
\hline Gift & 76,8 & 9,1 & 0 & Referanse \\
\hline Ugift & 75,3 & 8,9 & $-1,0$ & $-1,6$ til $-0,4$ \\
\hline Enkemann & 75,1 & 8,8 & $-1,2$ & $-2,4$ til $+0,1$ \\
\hline Separert/skilt & 74,3 & 8,5 & $-1,9$ & $-3,0$ til $-0,8$ \\
\hline Ukjent & 75,5 & 9,3 & $-0,5$ & $-2,1$ til $+1,2$ \\
\hline \multicolumn{5}{|l|}{ Bostedsregion 1960 (fylkesnummer) } \\
\hline Oslo-Akershus $(03,02)$ & 76,5 & 9,0 & 0 & Referanse \\
\hline$\emptyset$ stlandet for øvrig $(01,04-08)$ & 76,6 & 9,0 & $+0,3$ & $-0,1$ til $+0,6$ \\
\hline Sør-Norge (09-11) & 76,6 & 9,4 & $+0,4$ & $-0,1$ til $+0,9$ \\
\hline Vest-Norge (12-14) & 77,8 & 9,1 & $+1,3$ & $+0,7$ til $+1,9$ \\
\hline Midt-Norge (15-17) & 76,2 & 9,0 & $-0,2$ & $-0,7$ til $+0,4$ \\
\hline Nord-Norge (18-20) & 76,0 & 9,0 & $-0,3$ & $-1,1$ til $+0,6$ \\
\hline Ukjent & 75,5 & 9,3 & -2 & \\
\hline \multicolumn{5}{|l|}{ Næringsgruppe 1960} \\
\hline Primær & 77,7 & 9,0 & $+0,9$ & $-0,1$ til $+1,9$ \\
\hline Sekundær & 76,5 & 9,0 & $-0,3$ & $-0,7$ til $+0,1$ \\
\hline Tertiær & 76,9 & 9,1 & 0 & Referanse \\
\hline Ukjent & 76,2 & 9,3 & $-0,3$ & $-1,2$ til $+0,6$ \\
\hline \multicolumn{5}{|l|}{ Yrkesgruppe 1960} \\
\hline Ikke-manuell & 77,8 & 9,2 & 0 & Referanse \\
\hline Manuell & 76,3 & 9,0 & $-1,3$ & $-1,7$ til $-0,9$ \\
\hline Ukjent & 75,7 & 8,9 & $-1,4$ & $-2,1$ til $-0,8$ \\
\hline \multicolumn{5}{|l|}{ Systolisk blodtrykk (mm Hg) } \\
\hline$<125$ & 78,2 & 9,1 & 0 & Referanse \\
\hline $125-134$ & 77,6 & 8,9 & $-0,6$ & $-1,0$ til $-0,2$ \\
\hline $135-144$ & 76,8 & 8,9 & $-1,5$ & $-1,9$ til $-1,1$ \\
\hline $145-154$ & 75,1 & 8,7 & $-3,1$ & $-3,6$ til $-2,6$ \\
\hline $155-164$ & 74,3 & 9,0 & $-4,0$ & $-4,6$ til $-3,4$ \\
\hline $165-174$ & 73,1 & 8,5 & $-5,4$ & $-6,2$ til $-4,7$ \\
\hline $175-184$ & 73,5 & 8,7 & $-5,0$ & $-5,9$ til $-4,1$ \\
\hline $185-194$ & 71,6 & 8,4 & $-6,5$ & $-7,9$ til $-5,1$ \\
\hline$\geq 195$ & 71,0 & 8,4 & $-7,4$ & $-8,7$ til $-6,2$ \\
\hline Ukjent & 75,8 & 10,3 & $-3,6$ & $-5,6$ til $-1,5$ \\
\hline \multicolumn{5}{|l|}{ Kroppsmasseindeks (BMI) (kg/m²) } \\
\hline Undervekt $(<18,5)$ & 74,7 & 9,2 & $-1,7$ & $-3,0$ til $-0,5$ \\
\hline Normalvekt $(18,5-24,99)$ & 76,8 & 9,0 & 0 & Referanse \\
\hline Overvekt $(25,0-29,99)$ & 76,6 & 9,1 & $+0,1$ & $-0,2$ til $+0,3$ \\
\hline Fedme $(\geq 30)$ & 74,2 & 8,7 & $-1,4$ & $-2,1$ til $-0,7$ \\
\hline Ukjent & 76,9 & 9,9 & $+1,7$ & $-0,1$ til $+3,6$ \\
\hline \multicolumn{5}{|l|}{ Sigarettrøyking } \\
\hline Ikke-røyker & 77,9 & 9,1 & 0 & Referanse \\
\hline 1-4 sigaretter daglig & 76,9 & 8,9 & $-0,9$ & $-1,5$ til $-0,4$ \\
\hline $5-14$ sigaretter daglig & 75,3 & 8,7 & $-2,4$ & $-2,8$ til $-2,0$ \\
\hline$\geq 15$ sigaretter daglig & 74,1 & 8,7 & $-3,5$ & $-4,0$ til $-3,0$ \\
\hline Ukjent & 76,7 & 9,1 & $-1,0$ & $-1,3$ til $-0,6$ \\
\hline \multicolumn{5}{|l|}{ Senkningsreaksjon } \\
\hline Ikke forhøyet & 77,2 & 9,0 & 0 & Referanse \\
\hline Tvilsomt forhøyet & 74,3 & 9,0 & $-2,4$ & $-3,0$ til $-1,9$ \\
\hline Sikkert forhøyet & 73,3 & 8,6 & $-3,3$ & $-3,8$ til $-2,8$ \\
\hline Ukjent & 75,6 & 9,2 & $-1,4$ & $-2,5$ til $-0,4$ \\
\hline Konstant & & & 82,6 & 82,1 til 83,2 \\
\hline
\end{tabular}

1 Justert for fødselsår og alle faktorene i tabellen $\left.\right|^{2}$ Estimat droppet på grunn av kolinearitet 


\section{Diskusjon}

Denne studien viser at selv etter flere tiårs oppfølging var velkjente risikofaktorer som blodtrykk, sigarettrøyking og fedme målt ved rutinemessige helsekontroller hos bedriftslege forbundet med redusert livslengde - både totaldød og årsaksspesifikk død. Resultatene antyder at det er en sosioøkonomisk gradient i levealder, selv om materialet er for homogent sammensatt av manuelle arbeidere i sekundærnæringen til at dette kan vurderes i nærmere detalj.

Det unike med denne studien er at vi har kunnet følge studiepopulasjonen helt til nesten alle var døde. Siden svært få utvandret, kunne vi analysere prediktorer for alder ved død ved enkel multippel regresjon. En rekke diagnostiske tester har vist at en additiv modell passer godt (ikke presentert) og at den kombinerte effekten av ulike kovariater kan finnes ved summasjon av effekter. For eksempel hadde menn med referanseverdier av alle faktorer en gjennomsnittlig levealder på 82,6 år. Med et systolisk blodtrykk på mellom 165 mm Hg og 174 mm Hg og rapportert røyking av minst 15 sigaretter daglig, var den estimerte levealder i gjennomsnitt 73,9 år, dvs. nær ni år lavere. Gjennomsnittlig levealder presentert på denne måten er intuitivt lett å forstå og gir informasjon utover hasardratioer som presenteres fra overlevelsesanalyser.

Helseundersøkelsene i Linoljeforsøket ble utført for nær 50 år siden blant arbeidsføre menn. De fleste var manuelle arbeidere på Østlandet, og alle arbeidet $\mathrm{i}$ virksomheter med bedriftshelsetjeneste. Man kan derfor reise spørsmål ved generaliserbarheten av funnene i studien. Det er også en svakhet at vi ikke kjenner til senere endringer når det gjelder risikofaktorene, og vi kan derfor ikke anslå betydningen av eventuell blodtrykksmedisinering, røykeslutt eller vektendring.

I beregningene av tapte leveår vil effektene av ekstremnivåene av risikofaktorene bli undervurdert fordi de 372 som var i live ut 2005 ikke er inkludert i de lineære regresjonsanalysene. De fleste av disse hadde en gunstig risikoprofil (e-tab 1). Hvis de var blitt inkludert, ville de ha trukket estimatene for alder ved død oppover for dem med gunstig profil. Gitt at alle de 372 levde til de ble 100 år, ville regresjonsanalysen gitt estimater for tapte leveår som var 0,4 år høyere for blodtrykk $\geq 195 \mathrm{~mm} \mathrm{Hg} \mathrm{og} \mathrm{0,7} \mathrm{år} \mathrm{høyere}$ for røyking av $\geq 15$ sigaretter daglig sammenliknet med tilsvarende estimater i tabell 3.

\section{Blodtrykkseffekter}

Vi fant en betydelig effekt av høyt blodtrykk, med fem tapte leveår for deltakere med systolisk blodtrykk $\geq 160 \mathrm{~mm} \mathrm{Hg} \mathrm{sam-}$ menliknet med deltakere med $<125 \mathrm{~mm} \mathrm{Hg}$. Blodtrykkseffekten avtok over tid. Dette er i samsvar med resultatene av 33 års oppfølging i Oslo-undersøkelsen (13). Styrken på assosiasjonene mellom en økning i systolisk blodtrykk på $15 \mathrm{~mm} \mathrm{Hg} \mathrm{og} \mathrm{død} \mathrm{av} \mathrm{iskemisk}$

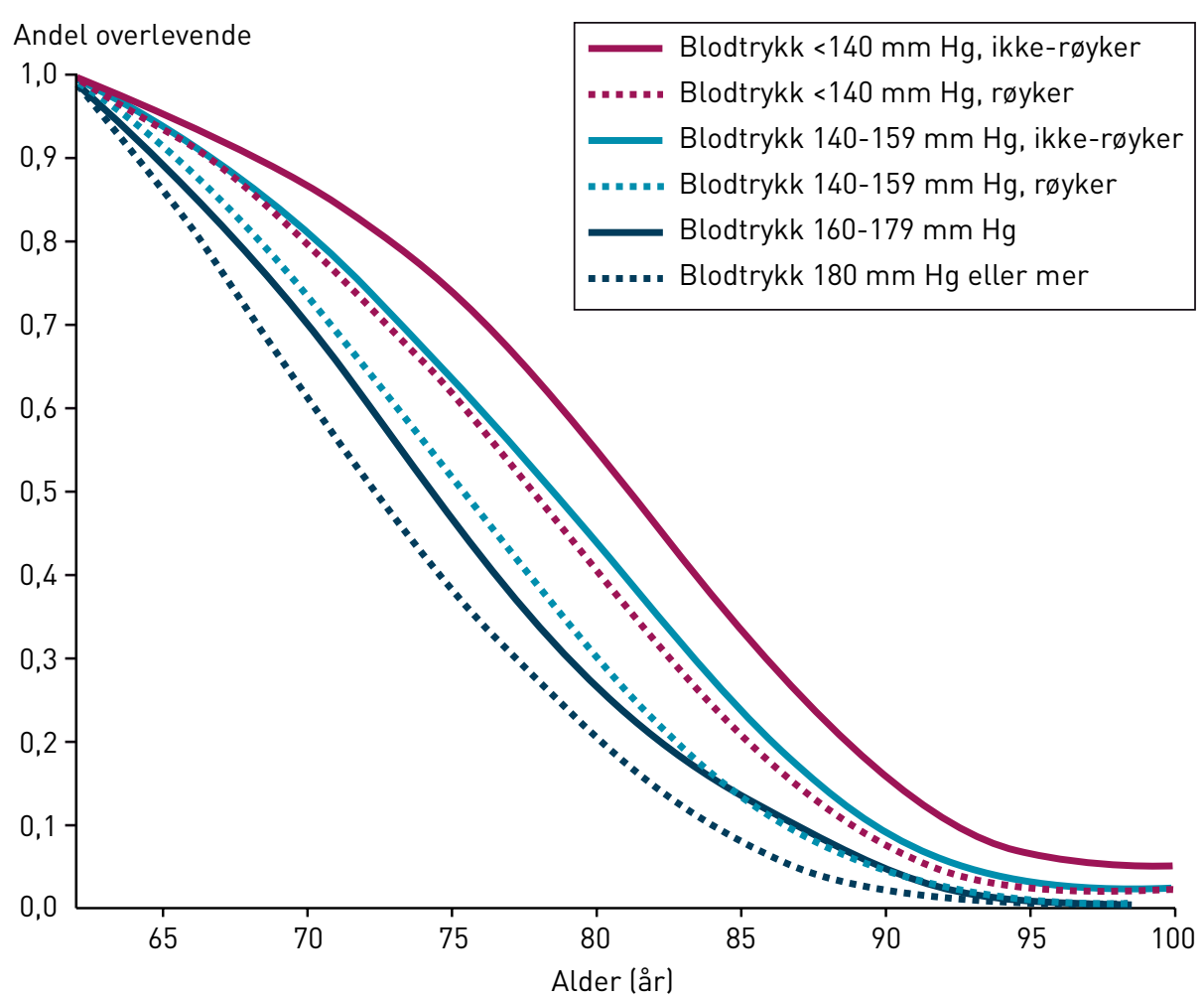

Figur 1 Overlevelse med oppfølging fra 62 års alder gruppert etter utvalgte kategorier av systolisk blodtrykk og røykevaner hos deltakere i Linoljeforsøket som var i arbeid i 1967 hjertesykdom eller slag ved oppfølging over 20 år var nesten identisk med tilsvarende oppfølging i blodtrykksundersøkelsen i Bergen (tabell 4 i referanse 12). Dette kan tyde på at blodtrykksmålingene hadde samme prediktive verdi som blodtrykksdataene fra Bergens-undersøkelsen, selv om Linoljeforsøket var basert på rutinemessige helseundersøkelser i forkant av prosjektet og sannsynligvis belemret med større tilfeldige målefeil.

Blodtrykk i Bergens-undersøkelsen var basert på den siste av to målinger, i Linoljeforsøket var det basert på en ustandardisert og ikke presist beskrevet målemetode, i tillegg til at det var langt flere som gjennomførte målingene. Tilfeldige målefeil og intraindividuelle variasjoner i blodtrykk fører til

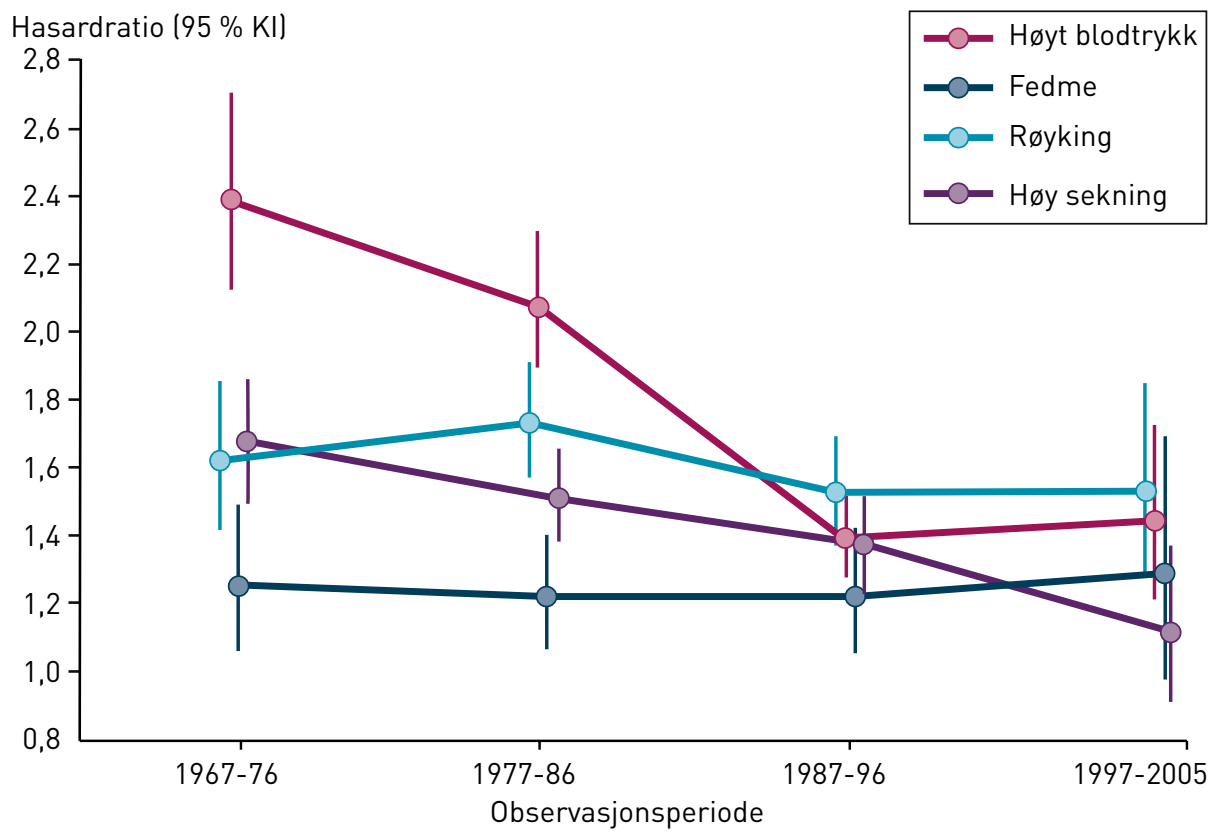

Figur 2 Hasardratio med 95 \% konfidensintervall (KI) for død i fire oppfølgingsperioder mellom 1967 og 2005 fordelt på utvalgte risikofaktorer hos deltakere i Linoljeforsøket som var i arbeid i 1967. Høyt blodtrykk: systolisk blodtrykk $\geq 160 \mathrm{~mm} \mathrm{Hg}$ versus < $125 \mathrm{~mm} \mathrm{Hg}$; fedme: BMI $\geq 30 \mathrm{~kg} / \mathrm{m}^{2}$ versus 18,5-24,99 kg/m²; røyking: $\geq 15$ sigaretter daglig versus ikke-røyker; høy senkning: sikkert forhøyet versus ikke forhøyet 
en underestimering av sammenhengen med dødelighet. I risikomodellen NORRISK er hasardratioen per $15 \mathrm{~mm} \mathrm{Hg}$ systolisk blodtrykk 1,35 for sirkulasjonssykdommer totalt (15), det vil si litt høyere enn verdien 1,27, som vi fant. Dette kan skyldes flere tilfeldige målefeil $i$ vår studie.

Vi observerte en svakere sammenheng mellom blodtrykk og dødelighet etter 20 års oppfølging. Dette kan skyldes at blodtrykket kan ha endret seg og at deltakerne er blitt 20 år eldre, med gjennomsnittsalder på nesten 80 år. Det kan også skyldes at flere er blitt satt på blodtrykksbehandling. I den første delen av oppfølgingsperioden var det mye mindre blodtrykksbehandling i befolkningen enn det er i dag. Én tolking av våre funn kan være at effekten av høyt blodtrykk blant personer som ikke har fått behandling er minst det vi har observert. Dette har også relevans for dagens medisin.

\section{Røykeeffekter}

De negative effektene av røyking var svakere enn i andre undersøkelser $(9,17)$, med hasardratioestimater assosiert med røyking av minst 15 sigaretter daglig på 1,3 for iskemisk hjertesykdom og 5,5 for lungekreft. Til sammenlikning ga en oppfølging av menn i store norske helseundersøkelser hasardratioestimater for død av lungekreft på 17 og 3 for henholdsvis dagligrøykere og tidligere røykere versus aldrirøykere (tabell $4.25 \mathrm{og}$ tabell 4.17 i referanse 18).

For dødelighet av iskemisk hjertesykdom var tilsvarende hasardratioestimater for dagligrøykere og tidligere røykere henholdsvis 3,3 og 1,5 for deltakere yngre enn 65 år og 1,7 og 1,3 for dem over 65 år (tabell $4.17 \mathrm{i}$ referanse 18). Den lange oppfølgingstiden kan ikke være forklaringen, da hasardratioestimatene for død av alle årsaker holdt seg stabile over tid, i likhet med det som var tilfellet i Oslo-undersøkelsen (13).

Røykedataene var, som i mange andre undersøkelser, basert på egenrapportering, og vi har ikke grunnlag for å anta at opplysningene skilte seg kvalitetsmessig fra dem i andre studier. Derimot kan det være mulig at angivelsen av daglig sigarettkonsum i 1960årene er mangelfull - ved at den gir en systematisk overestimering av deltakernes historiske tobakkseksponering. Dette kan være tilfellet fordi deltakerne vokste opp i tidlige faser av røykeepidemien. De var i 30-årene da krigen sluttet og har derfor sannsynligvis debutert som røykere relativt sent i livet og med mer moderat konsum i ung alder, sammenliknet med dem som kom inn i senere faser av røykeepidemien $(19,20)$.

En slik tolking har støtte i resultatene av 50 års oppfølging av britiske leger, hvor økningen i dødelighet for røykerne var mer beskjeden for leger født før 1900 sammenliknet med leger født i perioden 1900-30 (14). Tolkingen var at de senere kohortene startet røykingen tidligere og med høyere intensitet (17). En annen mulig forklaring kan være at vår referansekategori omfattet tidligere røykere. Vi vet ikke hvor mange av ikke-røykerne som hadde røykt tidligere.

\section{Effekter av kroppsmasseindeks}

I tråd med andre studier viste også denne studien en U-formet sammenheng mellom kroppsmasseindeks og død av alle årsaker, med estimert tapte leveår på 1,7 og 1,4 for henholdsvis undervektige $\left(<18,5 \mathrm{~kg} / \mathrm{m}^{2}\right)$ og fete $\left(\geq 30 \mathrm{~kg} / \mathrm{m}^{2}\right)$, mens det var liten variasjon i dødelighet for en kroppsmasseindeks mellom $18,5 \mathrm{~kg} / \mathrm{m}^{2}$ og $30 \mathrm{~kg} / \mathrm{m}^{2}$.

Risikoen for å dø av sirkulasjonssykdommer økte jevnt med økende kroppsmasseindeks, mens det var en negativ assosiasjon for respirasjonssykdommer og ytre årsaker. Dette samsvarer med tidligere funn (21-24). Risikoøkningen for død av lungekreft med lav kroppsmasseindeks var svakere $\mathrm{i}$ vår studie enn i den store internasjonale Prospective studies collaboration (24). Dette kan skyldes den relativt svake sammenhengen med røykevaner i vår studie.

\section{Assosiasjoner med forhøyet senkningsreaksjon}

Tidligere oppfølging i Linoljeforsøket har vist at det var overrisiko for koronar hjertesykdom (3) og død (10) hos deltakere med vedvarende høy senkningsreaksjon. Vår studie indikerer at disse assosiasjonene vedvarte over flere tiår, selv om de ble svekket etter hvert. Disse funnene er i samsvar med resultatene $\mathrm{i}$ andre studier $(25,26)$. Den mest nærliggende tolkingen er at kroniske inflammasjonsprosesser kan være en årsaksfaktor eller utgjøre et ledd i den patogenetiske prosessen ved aterosklerose $(26,27)$.

Dette kan også ses i sammenheng med CRP-nivå (C-reaktivt protein). Dette er en uspesifikk inflammasjonsmarkør hvor forhøyede konsentrasjonsnivåer er blitt koblet til økt risiko for blant annet hjerte- og karsykdom (28). Én enkelt CRP-måling har vist seg å forbedre risikoprediksjoner for koronar hjertesykdom utover de tradisjonelle risikofaktorene (29). Assosiasjonene med lungekreftdød og død av sykdom i respirasjonssystemet kunne forklares av liknende kroniske inflammasjonsprosesser.

Derimot er det vanskeligere å forklare assosiasjonen med ytre årsaker. Dette kan være et tilfeldig funn, men kan også skyldes uidentifisert og ukjent effektforveksling (konfundering).

\section{Konklusjon}

Etter en oppfølging på 40 år av mer enn 15000 menn i 50-årene var nesten alle døde. Alder ved død var under hele oppfølgingen assosiert med godt dokumenterte risikofaktorer målt før studiestart. Dette viser at resultatene ved rutinemessige helsekontroller i bedriftshelsetjenesten kan predikere overlevelse gjennom flere tiår. Dokumentasjonen av dette kan være et argument som støtter gjennomføring av slike helsekontroller og som muligens kan innebære et forebyggende potensial - i den grad funnene blir fulgt opp medisinsk.

Vi takker Ola Thune, NAV, og Geir Skjeret, Forsvarets sanitet, som har tilrettelagt datafilene for analyse.

e-tab 1, e-tab 2, e-tab 4 og e-tab 5 finnes kun i Tidsskriftets nettutgave.

\section{Tor Bjerkedal (f. 1926)}

er dr.med. og master of public health fra Harvard. Han har vært professor i medisin (hygiene) ved Universitet i Bergen og ved Universitetet i Oslo, medisinsk konsulent i Rikstrygdeverket, forsker ved Institutt for militærmedisinsk epidemiologi ved Forsvarets sanitet og er fra 1996 professor emeritus ved Institutt for helse og samfunn, Universitetet i Oslo. Ingen oppgitte interessekonflikter.

\section{Petter Kristensen (f. 1944)}

er dr.med., overlege og forskningssjef ved Avdeling for arbeidsmedisin og epidemiologi, Statens arbeidsmiljøinstitutt, og professor II ved Institutt for helse og samfunn, Universitetet i Oslo.

Ingen oppgitte interessekonflikter.

\section{Randi Selmer (f. 1953)}

er dr.philos., statistiker og seniorforsker ved Divisjon for epidemiologi, Folkehelseinstituttet. Ingen oppgitte interessekonflikter.

\section{Litteratur}

1. Owren PA, Hellem AJ, Ödegaard A. Linolenic acid for the prevention of trombosis and myocardial infarction. Lancet 1964: 284: 975-9.

2. Natvig H. Effekten av umettede fettsyrer på hyppigheten av hjerteinfarkt m.m. Resultatet av bedriftslegenes «oljeforsøk». Tidsskr Nor Lægeforen 1967; 87: 1033-41.

3. Natvig H, Borchgrevink CF, Dedichen J et al. A controlled trial of the effect of linolenic acid on incidence of coronary heart disease. The Norwegian vegetable oil experiment of 1965-66. Scand J Clin Lab Invest Suppl 1968; 105: 1-20.

4. Bruusgaard A. Forekomsten av hjerteinfarkt blan 60000 arbeidstakere under bedriftslægekontroll: foreløpig meddelelse. Tidsskr Nor Lægeforen 1960; 80: 797-9.

5. Westlund K, Nicolaysen R. Ten-year mortality and morbidity related to serum-cholesterol. A followup of 3.751 men aged 40-49. Scand J Clin Lab Invest Suppl 1972: 127: 1-24

6. Berg KJ, Skaga E, Skjæggestad O et al. Effect of linseed oil on platelet adhesiveness and bleedingtime in patients with coronary heart-disease. Lancet 1965: 2: $980-2$.

7. Lewington S, Clarke R, Qizilbash $\mathrm{N}$ et al. Age-specific relevance of usual blood pressure to vascular mortality: a meta-analysis of individual data for one million adults in 61 prospective studies. Lancet 2002: 360: 1903-13.

8. Whitlock G, Lewington S, Sherliker P et al. Bodymass index and cause-specific mortality in 900000 adults: collaborative analyses of 57 prospective studies. Lancet 2009; 373: 1083-96.

9. Vollset SE, Selmer R, Tverdal A et al. Hvor dødelig er røyking? Rapport 4: 1-24. Oslo: Nasjonalt folkehelseinstitutt, 2006 
10. Natvig H, Bjerkedal T. Dødsrisiko, kliniske funn og laboratorieprøver hos 50-59 år gamle menn resultater av 17 års oppfølging av deltagerne i «Oljeforsøket» i 1964/65. Norsk bedriftshelsetjeneste 1986; 7: 5-16.

11. Holmboe J. Helsekontroller - kjekt å ha? Tidsskr Nor Lægeforen 1996; 116: 2067-8.

12. Selmer R. Blood pressure and twenty-year mortality in the city of Bergen, Norway. Am J Epidemiol 1992; 136: 428-40.

13. Holme I, Tonstad S. Risikofaktorer og dødelighet oppfølging av Oslo-undersøkelsen fra 1972-73. Tidsskr Nor Legeforen 2011; 131: 456-60.

14. Conroy RM, Pyörälä K, Fitzgerald AP et al. Estimation of ten-year risk of fatal cardiovascular disease in Europe: the SCORE project. Eur Heart J 2003; 24: $987-1003$.

15. Selmer R, Lindman AS, Tverdal A et al. Modell for estimering av kardiovaskulær risiko i Norge. Tidsskr Nor Legeforen 2008; 128: 286-90.

16. Williams B, Lindholm LH, Sever P. Systolic pressure is all that matters. Lancet 2008; 371 2219-21.

17. Doll R, Peto R, Boreham J et al. Mortality in relation to smoking: 50 years' observations on male British doctors. BMJ 2004; 328: 1519.

18. Selmer R. Helsemessige og økonomiske konsekvenser av tobakksrøyking: Hvor stor andel av sykelighet og dødelighet i Norge i ett år kan tilskrives tobakksrøyking? I: Norges offentlige utredninger. Tobakksindustriens erstatningsansvar. NOU 2000: 16: 429-80.

19. Rønneberg A, Lund KE, Hafstad A. Lifetime smoking habits among Norwegian men and women born between 1890 and 1974. Int J Epidemiol 1994; 23: $267-76$.

20. Lund KE, Lund M, Bryhni A. Tobakksforbruket hos kvinner og menn 1927-2007. Tidsskr Nor Legeforen 2009; 129: 1871-4.

21. Engeland A, Bjørge T, Selmer RM et al. Height and body mass index in relation to total mortality. Epidemiology 2003; 14: 293-9

22. Koch D. Waaler revisited: the anthropometrics of mortality. Econ Hum Biol 2011; 9: 106-17.

23. Waaler HT. Height, weight and mortality. The Norwegian experience. Acta Med Scand Suppl 1984: 679: $1-56$.

24. Whitlock G, Lewington S, Sherliker P et al. Bodymass index and cause-specific mortality in 900000 adults: collaborative analyses of 57 prospective studies. Lancet 2009; 373: 1083-96.

25. Gillum RF, Mussolino ME, Makuc DM. Erythrocyte sedimentation rate and coronary heart disease: the NHANES I Epidemiologic Follow-up Study. J Clin Epidemiol 1995; 48: 353-61.

26. Andresdottir MB, Sigfusson N, Sigvaldason $\mathrm{H}$ et al. Erythrocyte sedimentation rate, an independent predictor of coronary heart disease in men and women: the Reykjavik Study. Am J Epidemiol 2003 158: 844-51.

27. Ross R. Atherosclerosis - an inflammatory disease. N Engl J Med 1999; 340: 115-26.

28. Bisoendial RJ, Boekholdt SM, Vergeer M et al. $\mathrm{C}$-reactive protein is a mediator of cardiovascular disease. Eur Heart J 2010; 31: 2087-91.

29. Cushman M, Arnold AM, Psaty BM et al. C-reactive protein and the 10-year incidence of coronary heart disease in older men and women: the cardiovascular health study. Circulation 2005; 112: 25-31.

Mottatt 2.5. 2011, første revisjon innsendt 28.9. 2011, godkjent 20.10. 2011. Medisinsk redaktør Erlend T. Aasheim 